\title{
Increased precipitation enhances the rate of the soil respiration in a semi-arid area of the Loess Plateau, China
}

\author{
Yutao Wang ${ }^{1}$, Yingzhong Xie ${ }^{1}$, Gillian L. Rapson ${ }^{2}$, Hongbin Ma ${ }^{1}$, Le Jing ${ }^{1}$, Yi Zhang ${ }^{1}$, Juan Zhang ${ }^{1}$, Jianping Li \\ Corresp. 1 \\ ${ }^{1}$ School of agriculture, Ningxia University, Yinchuan, Ningxia, China \\ 2 School of Agriculture and Environment, Massey University, Palmerston North, New Zealand \\ Corresponding Author: Jianping Li \\ Email address: lijianpingsas@163.com
}

Background. Precipitation influences the vulnerability of grassland ecosystems, especially upland grasslands, and soil respiration is critical for carbon cycling in arid grassland ecosystems which typically experience more droughty conditions. Methods. We used three precipitation treatments to understand the effect of precipitation on soil respiration of a typical arid steppe in the Loess Plateau in north-western China.

Precipitation was captured and relocated to simulate precipitation rates of $50 \%, 100 \%$, and $150 \%$ of ambient precipitation. Results and Discussion. Soil moisture was influenced by all precipitation treatments. Shoot biomass was greater, though non-significantly, as precipitation increased. However, both increase and decrease of precipitation significantly reduced root biomass. There was a positive linear relationship between soil moisture and soil respiration in the study area during the summer (July and August), when most precipitation fell. Soil moisture, soil root biomass, $\mathrm{pH}$, and fungal diversity were predictors of soil respiration based on partial least squares regression, and soil moisture was the best of these. Conclusion. Our study highlights the importance of increased precipitation on soil respiration in drylands. Precipitation changes can cause significant alterations in soil properties, microbial fungi, and root biomass, and any surplus or transpired moisture is fed back into the climate, thereby affecting the rate of soil respiration in the future. 
1 Increased precipitation enhances the rate of the soil respiration in a semi-arid area of the

2 Loess Plateau, China

3 Yutao Wang ${ }^{1}$, Yingzhong Xie ${ }^{1}$, Gillian L. Rapson ${ }^{2}$, Hongbin $\mathrm{Ma}^{1}$, Le Jing ${ }^{1}$, Yi Zhang ${ }^{1}$, Juan

4 Zhang ${ }^{1}$, Jianping $\mathrm{Li}^{1, *}$

$5{ }^{1}$ School of Agriculture, Ningxia University, Yinchuan, Ningxia, China

$6{ }^{2}$ School of Agriculture and Environment, Massey University, Private Bag 11-222 Palmerston

$7 \quad$ North 4442, New Zealand

8

9 *Corresponding Author:

10 Jianping Li

11 Ningxia University, Helanshan West Road, Xixia District, Yinchuan, Ningxia, 750021, China

12 Email address: lijianpingsas@163.com 


\section{Abstract}

Background. Precipitation influences the vulnerability of grassland ecosystems, especially upland grasslands, and soil respiration is critical for carbon cycling in arid grassland ecosystems which typically experience more droughty conditions.

Methods. We used three precipitation treatments to understand the effect of precipitation on soil respiration of a typical arid steppe in the Loess Plateau in north-western China. Precipitation was captured and relocated to simulate precipitation rates of $50 \%, 100 \%$, and $150 \%$ of ambient precipitation.

Results and Discussion. Soil moisture was influenced by all precipitation treatments. Shoot biomass was greater, though non-significantly, as precipitation increased. However, both increase and decrease of precipitation significantly reduced root biomass. There was a positive linear relationship between soil moisture and soil respiration in the study area during the summer (July and August), when most precipitation fell. Soil moisture, soil root biomass, $\mathrm{pH}$, and fungal diversity were predictors of soil respiration based on partial least squares regression, and soil moisture was the best of these.

Conclusion. Our study highlights the importance of increased precipitation on soil respiration in drylands. Precipitation changes can cause significant alterations in soil properties, microbial fungi, and root biomass, and any surplus or transpired moisture is fed back into the climate, thereby affecting the rate of soil respiration in the future.

\section{Introduction}

Recent changes in global temperatures and precipitation patterns have occurred due to the increase in greenhouse gases (Gao et al. 2016). Temperatures are expected to gradually increase in most parts of the world and extremes are anticipated to become more frequent (Garrett et al. 2006). Global warming is expected to cause atmospheric water vapor to increase significantly and affect the hydrological cycle (O’Gorman \& Schneider 2009), impacting global precipitation patterns and causing regional precipitation changes (Pall et al. 2006). The intensity of precipitation events is expected to increase, and extreme precipitation events will occur more 
55

56

57

frequently according to the forecast of the Intergovernmental Panel on Climate Change (IPCC 2001).

Previous studies have indicated that changes in precipitation affect the dynamics of the terrestrial carbon cycle and terrestrial carbon pools (Ahlström et al. 2015; Felton et al. 2019; Frank et al. 2015; Wu et al. 2011). Water is a driving factor for chemical and biological processes in ecosystems, including plant survival, photosynthesis and respiration, heterotrophic respiration (Gerten et al. 2008; Zhang et al. 2019a), soil nutrient dynamics (Yuan et al. 2017), terrestrial ecosystem functioning ( $\mathrm{Wu}$ et al. 2009), and microbial activity, diversity, and respiration (Classen et al. 2015; Felton et al. 2019; Frank et al. 2015). Moreover, changes in global precipitation patterns exert profound effects on the nature of vegetation (Gao et al. 2016), especially in arid and semiarid regions where water is the main limiting factor for plant growth (Jing et al. 2010; Knapp et al. 2002).

Global emissions of $\mathrm{CO}_{2}$ from soil are considered to be one of the largest causes of flux in the global carbon cycle and small changes in soil respiration may have large impacts on atmospheric $\mathrm{CO}_{2}$ concentrations (Schlesinger \& Andrew 2000). Soil $\mathrm{CO}_{2}$ flux is sensitive to higher temperatures, since root exudates, root mycorrhizae, plant detritus, and other part of the plant have different temperature sensitivities to fluctuations in soil $\mathrm{CO}_{2}$ levels (Boone et al. 1998), which themselves strongly impact the terrestrial carbon cycle (Fischlin et al. 2007; Frank et al. 2015). However, we still have a poor understanding of the response of soil respiration as related to climate change (Fernandez et al. 2006).

Carbon fluxes have recently been studied in alpine meadows and show that only underground biomass and soil moisture have a direct effect on soil respiration (Geng et al. 2012). Studies on tropical forests have shown that higher elevation decreases in root and litter samples resulted in increases in soil respiration, with microbial respiration more closely related to soil moisture levels (Zimmermann et al. 2010). In arid temperate grasslands, soil respiration has a positive response to extreme precipitation events, affecting the ecosystem's carbon cycle (Thomey et al. 2011). However, there are few studies on semi-arid ecosystems which account for about $15 \%$ of 
82 the terrestrial area of the globe (Huang et al. 2015). They are especially sensitive to precipitation changes (Niu et al. 2019) . Often occurring in semi-arid areas, grasslands play a key role in the carbon cycle (Li et al. 2017; Poulter et al. 2014; Zhang et al. 2019b), while being very sensitive to large-scale climate change (Feng et al. 2006).

The upland Loess Plateau in northwestern China is a critical transition zone for semi-arid ecosystems in China (Zhao et al. 2014). It is predicted that temperature and precipitation will increase significantly in this area (Zhao et al. 2014), where we conducted field work to simulate increased and decreased precipitation exploring the factors affecting soil $\mathrm{CO}_{2}$ flux. Our study has great scientific and practical implications for the effects of precipitation on soil respiration and plant productivity and their roles in regional and global terrestrial carbon cycles. We sought to evaluate the differences in soil properties, plant biomass, and microbial diversity at different soil depths using different precipitation treatments, to determine the main factors affecting soil respiration in the study area.

Materials \& Methods

\section{Study sites}

The study was conducted at the Agriculture Experimental Station of Ningxia University, Yinchuan Province of China, in Yunwu Mountain of Guyuan, Ningxia $\left(106^{\circ} 21^{\prime} E-106^{\circ} 27^{\prime}\right.$ E, $\left.36^{\circ} 10^{\prime} \mathrm{N}-36^{\circ} 17^{\prime} \mathrm{N}\right)$. The climate of the area is temperate, continental monsoon. The annual average precipitation is about $439 \mathrm{~mm}$ and varied from $282 \mathrm{~mm}$ in 1982 to $706 \mathrm{~mm}$ in 2013 . More than $50 \%$ of the annual precipitation occurs in the summer months (June to August). The average annual temperature is $7.2{ }^{\circ} \mathrm{C}$, and varied from $5.3^{\circ} \mathrm{C}$ in 1984 to $8.7^{\circ} \mathrm{C}$ in 2013 . The average monthly minimum temperature for the coldest month (January) was $-7.2{ }^{\circ} \mathrm{C}$, and the average monthly maximum temperature for the warmest month (July) was $19.6{ }^{\circ} \mathrm{C}$. The annual evaporation is $1300-1640 \mathrm{~mm}$, and the annual duration for sunshine can reach $2500 \mathrm{~h}$, with a frost-free period of 112-140 days. The annual potential evapotranspiration is $1625 \mathrm{~mm}$ (meteorological data from 1981 to 2017 is from the National Meteorological Administration of China). The soils are grey-cinnamon and dark loessial, as classified by the Chinese soil 
109

110

111

112

113

114

115

116

117

118

119

120

121

122

123

124

125

126

127

128

129

130

131

132

133

134

135

classification system (National Soil Survey Office 1993). The vegetation is typical steppe and the main plant species are Stipa bungeana, Artemisia gmelinii, Stipa grandis, Artemisia frigida,

Potentilla acaulis and Agropyron michnoi (Wang et al. 2020).

\section{Experimental design}

Our research site was located in a semi-arid natural grassland that was left ungrazed for 19 years. The study area was at $2077 \mathrm{~m}$, with a 7-10 $0^{\circ}$ slope, and a south-facing, sunny aspect. Annual precipitation in 2019 was $592 \mathrm{~mm}$, which was $20 \%$ higher than average. We set three blocks with three $6 \times 6 \mathrm{~m}$ plots in each block, to make a total of 9 plots. Each trio of plots down the gradient was considered to be a block (Fig. 1). According to local multi-year meteorological data from the study area, the mean maximum and minimum precipitation levels were about $50 \%$ and $150 \%$ of the average annual precipitation. A Rain shelter was set up on each block. Each rainshelter was fixed to the ground by steel pillars, and transparent polyethylene plates were fixed in "V" shapes to intercept precipitation and channel it off the plot using the natural slope of the mountain, while forming a stable and well-ventilated structure (Afreen \& Singh 2019). Rain shelters intercepted half of the natural precipitation to form a reduced precipitation treatment (R50). The intercepted water was piped to an adjacent plot to form an increased precipitation area $(\mathrm{R} 150)$. The remaining three plots were the controls (R100). Snow was collected from the rain shelters after each snowfall (R50) and was sprinkled evenly into the R150 plots. Plastic barriers were used to prevent surface runoff or leakage of soil moisture between plots. Each barrier was buried at a depth of $1.1 \mathrm{~m}$ and projected $10 \mathrm{~cm}$ above ground. Our study ran from May 2017 to May 2019.

\section{Environmental factors}

We collected field data in July 2019 which corresponded to the annual period of peak biomass.

Three soil sample replicates were collected at depths of 0-9.9 cm, 10-19.9 cm, and 20-30 cm in each plot, after the litter was discarded. The soil samples were separated into two parts: one part was kept moist to determine the microbial diversity of the soil, and the other was air-dried for measurement of soil properties. 
136

137

138

139

140

141

142

143

144

Soil organic carbon (SOC) was measured by potassium dichromate-sulfuric acid digestion, with ammonium ferrous sulfate titration. Total nitrogen (TN) was determined using an Elementar analyzer (Elementar, Vario EL III, Germany). Total phosphorus (TP) was measured using Olsen's method (Bremner \& Mulvaney 1982). Soil pH was measured using a PHS-3C pH Meter in a 1:5 ratio of fresh soil: water slurry (Huakeyi, Beijing, China).

A $1 \mathrm{~m}^{2}$ quadrat was randomly selected in each subplot to determine the plant biomass. The litter was raked and bagged and the shoots of the plants were cut at ground level. Root biomass (RB) was sampled to $30 \mathrm{~cm}$ in three intervals of equal depth and the soil carefully brushed off the roots. All plant samples were dried at $65^{\circ} \mathrm{C}$ in an oven for 75 hours and then weighed.

Soil microbial diversity was determined based on the Illumina HiSeq sequencing platform of the Majorbio Cloud Platform (www.majorbio.com). The bacterial primer was 338F_806R and the fungal primer was ITS1F_ITS2R. Sobs' and Shannon's indices were used to indicate the alpha diversity of bacteria and fungi. Coverage index, as defined by Good (Good 1953) indicates the percentage of operational taxonomic units (OTUs) sampled in a microbial community (i.e. recovered per sample) as a percent of all OTUs found on the site (Chao 1984; Lemos et al. 2011).

\section{Measurements of soil respiration}

Soil respiration (release of $\mathrm{CO}_{2}$ ) was measured every 14-16 days by the LI-8100A portable gas exchange system from April 2019 to October 2019 (LiCor, Lincoln NE, USA; chamber 8100103, diameter of $20 \mathrm{~cm}$ ). Polyvinyl chloride (PVC) collars were set permanently in place in the soil one week before the first measurement to minimize soil disturbance. The height of each collar was $12 \mathrm{~cm}$ and the above-ground height was $3 \mathrm{~cm}$, with the soil surface area and volume within the collar being $317.8 \mathrm{~cm}^{2}$ and $953.4 \mathrm{~cm}^{3}$, respectively. Five collars were placed randomly in each plot, giving a total of 45 collars. The above-ground parts of the plants inside the collar were removed before taking each flux reading and the roots were left in place (Afreen \& Singh 2019). Soil fluxes were measured about every 16 days, between 9 am and 1 pm, based on weather conditions. The flux from each collar was measured for $100 \mathrm{~s}$. Soil moisture was measured at a depth of $5 \mathrm{~cm}$ with a GS-1 Licor sensor, and the temperature was measured 
163

164

165

166

167

168

169

170

171

172

173

174

175

176

177

178

179

180

181

182

183

184

185

186

187

188

189

concurrently at a depth of $10 \mathrm{~cm}$ using the Licor sensor 6000-09 TC. To avoid pseudo-replication, the five values per plot were averaged for each variable to get a single datum for each measurement timepoint.

\section{Statistical analysis}

Statistical analysis was conducted using IBM SPSS (IBM, Chicago, USA). One-way ANOVA was used to process the aboveground and underground biomass of plants under different precipitation treatments. A two-way ANOVA was used to process root biomass, soil nutrient content, soil $\mathrm{pH}$, and the microbial diversity index under different precipitation treatments and different soil depths. Microbial diversity was calculated by Mothur (Version v.1.30). Origin (Origin Lab 2017, Microcal, Massachusetts, USA) was used for figures. The different dates formed temporal pseudoreplication, so the significance was explored using nlme (https://svn.rproject.org/R-packages/trunk/nlme; Author Pinheiro J) in R (R Core Team 2013; Version 3.0.2) for soil temperature, soil moisture, and soil $\mathrm{CO}_{2}$ flux (using the format lme: flux $\sim$ Precipitations * Date, random $=\sim 1 \mid$ plot, weights $=$ varIdent (form $=\sim 1 \mid$ Date). The varIdent function in package Predictmeans v1.0.2 (https://www.rdocumentation.org/packages/predictmeans; Authors Luo D, Ganesh S, and Koolard J) was used to allow each timepoint to have a different variance. Package ggplot2 (https://www.rdocumentation.org/packages/ggplot2; Authors Wickham H. et al) was used for correlations of soil $\mathrm{CO}_{2}$ flux and all other factors to filter out some variables. For example, if the correlation between Soil SOC and Soil TN was high, we only selected one of these variables, and then performed sPLS analysis (Partial Least Squares regression)(http://mixomics.org/methods/spls/). By contrast, if the correlation between the two was poor, we performed sPLS on both variables. Finally, we considered including soil moisture, RB 0-19.9, soil $\mathrm{pH}$, soil fungi in a sPLS analysis to select variables influencing the predictive model of soil $\mathrm{CO}_{2}$ flux. Stepwise regression was used to model of the main factors affecting soil respiration.

\section{Results}

\section{Precipitation and temperature during the trial}


190 The annual precipitation was $420 \mathrm{~mm}, 550 \mathrm{~mm}$, and $592 \mathrm{~mm}$ in 2017-2019. In 2018 and 2019

191 precipitation was 30\% higher than the average level of precipitation for the last 40 years.

192 Precipitation in 2019 from April to October (the growing season) was $562 \mathrm{~mm}$, which was about $19395 \%$ of the average annual precipitation (Fig. 2). The average annual air temperature was $7.9{ }^{\circ} \mathrm{C}$ 194 in 2019, which was 9\% higher than the average temperatures from 1980 to 2019 . The highest

195 196

temperature was $19.7^{\circ} \mathrm{C}$ in July, and the lowest was $-6.6^{\circ} \mathrm{C}$ in January in 2019 (Fig. 2).

\section{Soil properties}

Two-way ANOVA results showed that, except for TP, soil properties had significant differences under precipitation treatments and at different soil depths $(P<0.05)$. Precipitation and soil depth gave the only significant interaction in SOC. The rest of the soil properties had their highest value under R100 in soil 0-30 cm deep (Table 1), with the exception of the soil TP. SOC was $23 \%$ greater under R50 as the depth of the soil layer was greater, followed by R100 (18\%) and R150 (14\%). SOC at R50 increased just $1 \%$ in the topsoil $(0-9.9 \mathrm{~cm})$ and decreased about $6 \%$ in soil depths of 20-30 cm, compared with R100, while R150 had same value with R100 in 20-30 cm soil depths but decreased about 3\% in the $0-9.9 \mathrm{~cm}$ soil band. As the depth of the soil layer increased, soil pH gradually increased. Soil TN and SOC were highest in the topsoil $(0-9.9 \mathrm{~cm})$, and decreased with soil depth.

\section{Biomass of shoot, litter and root}

There were no significant differences in shoot, litter, and total biomass $(\mathrm{TB}=$ sum of shoots, litter, and RB 0-30) under different precipitation treatments according to one-way ANOVA's results. Nevertheless, shoot biomass was greatest in R150, and was lower at lower precipitation. Litter biomass was greatest in R50. By contrast, root biomass (RB) 0-30 cm showed significant differences between precipitation treatments according to one-way ANOVA, with R100 having the most root biomass, and R150 and R50 being significantly lower by $52 \%$ and $65 \%$ when compared with R100, respectively (Fig. 3A). The total biomass under R50 was lower than for treatments R100 and R150. The shoot/root ratio (Aboveground biomass/RB), was largest in R150, and was significantly lower by $64 \%$ in R100 $(P<0.05)$ (Fig. 3B). 
217

218

219

220

221

222

223

224

225

226

227

228

229

230

231

232

233

234

235

236

237

238

239

240

241

242

243

Different precipitation treatments and soil depths caused significant differences in root biomasses according to two-way ANOVA. All values were lower at greater soil depths (Fig. 4). The highest value of root biomass appeared at 0-9.9 cm in R100; values in R50 and R150 at 0$9.9 \mathrm{~cm}$ were significantly lower by $68 \%$ and $57 \%$, respectively. Both increased precipitation and reduced precipitation significantly reduced the root biomass in the topsoil $(0-9.9 \mathrm{~cm})$ (Fig. 4).

\section{Microbial richness and diversity}

More than $95 \%$ of operational taxonomic units (OTUs) found in the microbial community at the study site were present in each soil sample examined. There was no significant difference in soil microbial richness via Sobs' index and diversity via Shannon's index under different precipitation treatments and for the precipitation*soil depth interaction. However, there was a significant difference in soil microbial richness and diversity with soil depth, and the value was greatest at 0-9.9 cm (Table 2). The Sobs' index and Shannon's index of bacteria and fungi gradually decreased at greater soil depth.

\section{Soil moisture, soil temperature and soil $\mathrm{CO}_{2}$ flux}

Soil moisture, soil temperature and soil $\mathrm{CO}_{2}$ flux showed significant differences between precipitation treatments over the entire experimental period (April - October) (Table 3).

Measurements over the growing season also differed significantly for all variates and were significantly affected by precipitation levels $(P<0.05)$ (Table 3$)$.

Soil moisture and $\mathrm{CO}_{2}$ flux were greater at higher levels of precipitation while soil temperature was lower (Table 4). The response of soil moisture to the decreased precipitation treatment (-37.2\% of R100) was greater than to increased precipitation (3.9\% of R100). Mean soil $\mathrm{CO}_{2}$ flux under R100 was higher by $38.9 \%$ than that for R50, while for R150 the increase relative to R100 was only $8.3 \%$ (Table 4 ).

All variables (soil moisture, soil temperature and soil $\mathrm{CO}_{2}$ flux) were strongly influenced by seasonality (Table 3). Soil moisture was highest in April and May, then dropped to rise again in October, giving a "W"-shaped relationship with time. Soil temperatures peaked in summer (June-August). The soil $\mathrm{CO}_{2}$ flux showed an upward trend from April to July, and peaked before 
244 decreasing to its lowest levels in October (Table 5).

245 Soil moisture was typically greatest in the R150 treatment, with the exception of April and

246 September (Fig. 5A). The highest soil temperature values were typically seen in R50 (Table 4),

247 but this situation was reversed in June and July (summer; Fig. 5B), when precipitation was high

248 (Fig. 2). Overall, the soil temperature first rose and then decreased during the growing season.

249 Soil $\mathrm{CO}_{2}$ flux showed the same trends as soil moisture for most months. The soil $\mathrm{CO}_{2}$ flux was

250 lower at the lower end of the precipitation gradient and was highest at R150 and lowest at R50.

251 However, across the summer months, early May and early July, with enhanced precipitation

252 (R150), the soil $\mathrm{CO}_{2}$ flux was slight lower about 1\%-10\%, compared to R100 (Fig 5C). By

253 contrast, precipitation had little effect on soil $\mathrm{CO}_{2}$ flux in the autumnal month of October.

\section{Modeling soil $\mathrm{CO}_{2}$ flux}

255 Based on the results of the correlation analysis (Fig. S1), sPLS analysis was performed and 256 showed that the factors most closely correlated with soil respiration were soil moisture, root 257 biomass (RB 0-9.9, RB 10-19.9), soil pH, and fungal diversity (Fig. S2). Stepwise regression 258 showed that soil moisture was the only input factor that significantly affected soil $\mathrm{CO}_{2}$ flux $(P<$ $2590.001, \mathrm{R}=0.94$, adjusted $\mathrm{R}^{2}=0.870$ ), and all other variables were excluded (Table 6).

\section{Discussion}

261 Soil organic carbon (SOC), total soil nitrogen (TN) and $\mathrm{pH}$ were significantly different in the

262

263

264

265

266

267

268

269

270 three precipitation treatments, having their highest values in R100, while both increased and decreased precipitation reduced these values. Nutrients in the soil can accumulate through the degradation of plants, litter, and root secretions (Qiu et al. 2009; Zhang et al. 2016). Our study showed that different precipitation treatments had no significant impact on biomass of shoots and litter, but there was a significant effect on the root biomass. Increases and decreases in precipitation also significantly reduced root biomass, which was significantly higher in R100, especially in the topsoil $(0-9.9 \mathrm{~cm})$. Changes in precipitation may influence a plant's growth as related to the balanced growth hypothesis (Shipley \& Meziane 2002). Plants will preferentially distribute any acquired water to the root in semi-arid areas (Afreen \& Singh 2019). Therefore, 
271

272

273

274

275

276

277

278

279

280

281

282

283

284

285

286

287

288

289

290

291

292

293

294

295

296

297

soil properties under different precipitation treatments may be more affected by the root biomass, as root decomposition and roots' secretions will cause differences in SOC, TN and pH. We found that as precipitation decreased (R50) in the study area, the water requirements for grass growth were no longer met, and root biomass was significantly lower compared with that in R100. As precipitation increased in the summer, the root biomass was higher in R150 than R50 and R100.

The indices for soil microbial diversity and richness were unresponsive to the three precipitation treatments, but were responsive to different soil depths. While previous studies have suggested that water supply is positively correlated with the richness and diversity of the community (Hawkins et al. 2003), this rule does not necessarily apply to soil microorganisms (Bachar et al. 2010), which may instead be determined by physical isolation of microbial populations (Treves et al. 2003). In addition, short-term precipitation changes of 1 or 2 years have little effect on microbial diversity (Wang et al. 2020).

Soil moisture, soil temperature, and soil respiration showed significant seasonal differences under different precipitations throughout the experiment. Soil moisture and soil respiration increased with the precipitation gradient, but soil temperature showed the opposite, downward, trend. Soil temperature may be affected by coverage of surface vegetation (Kang et al. 2000), which increases with increasing precipitation in semi-arid environments; the canopy intercepts solar radiation and reduces evaporation, thus lowering soil and air temperatures. Plant biomass is lowest in R50, which had the largest area of bare land and thus probably experienced more evaporation from the bare soil. The higher the soil moisture, the greater the specific heat capacity, so that occurrence of more soil water may lower the soil temperature.

Generally, changes of soil temperature reflected atmospheric temperature in the study area except at very high temperatures, and more precipitation had a weakening effect on the relationship between air and soil temperatures. Temperature regulates soil respiration by changing the rate at which organisms process carbon and nutrients (Crowther \& Bradford 2013). Our study showed there was no significant correlation between soil respiration and soil temperature during vigorous plant growth, which may be related to our brief experimental period, 
298

299

300

301

302

303

304

305

306

307

308

309

310

311

312

313

314

315

316

317

318

319

320

321

322

323

324

only two years. Studies indicate that the temperature sensitivity of soil respiration will decrease under continuous global warming (Peng et al. 2009). In addition, an increasing number of studies show that soil respiration responds more strongly to precipitation pulses rather than soil warming pulses in regions limited by water (Almagro et al. 2009).

Changes in soil moisture content and precipitation were not closely correlated, but showed high values in spring and autumn and trended in a "W" shape during the growing season. In the spring melting snow replenished the soil moisture, and lower evapotranspiration kept the soil moist. However, high temperature with high evapotranspiration reduced the soil moisture in the study area in summer and limited growth. Precipitation events in water-limited areas usually only affect the topsoil and this water is easily lost by direct evaporation (Schwinning \& Sala 2004), resulting in no soil moisture gains. Generally, soil moisture accumulates as air temperature drop and evapotranspiration losses are decreased in autumn (Felton et al. 2019; Maes \& Steppe 2012; Wang et al. 2013). We found that, under increased precipitation, soil moisture was increased in May and then decreased towards September.

Literature has indicated that other non-negligible factors affecting soil moisture include soil permeability, surface runoff, evaporation, and evapotranspiration (Wang et al. 2012). We found that surface run-off could be negated with the use of a plastic barrier with an underground depth of $110 \mathrm{~cm}$ and a ground height of $10 \mathrm{~cm}$. A bigger root system can improve soil permeability, aeration, and porosity (Ozalp et al. 2016). In our experiment, the greater root biomass caused by increased precipitation may have resulted in improved soil permeability and moisture storage, increasing soil moisture. At the same time, the higher above-ground biomass and canopy coverage under the increased precipitation treatment may have had an inhibiting effect on surface evaporation, which is intense in arid areas, while the rain-reduction treatment experienced the opposite effect. Soil moisture is one of the main environmental factors affecting soil $\mathrm{CO}_{2}$ flux. Soil moisture affects the physiological performance of microorganisms and nutrient diffusion (Yuste et al. 2007), especially in arid areas with limited water conditions (Emmett et al. 2004; Lellei-Kovács et al. 2011; Zhang et al. 2010). A clear threshold effect links 
325

326

327

328

329

330

331

332

333

334

335

336

337

338

339

340

341

342

343

344

345

346

347

348

349

350

351

soil respiration with soil moisture (Balogh et al. 2011), and especially so in arid areas (Niu et al. 2019). Our study demonstrated that the total soil $\mathrm{CO}_{2}$ flux in $\mathrm{R} 150$ was higher than in $\mathrm{R} 50$

throughout the test period, but in April, June, and July when the soil moisture content was higher than in other months, the soil $\mathrm{CO}_{2}$ flux of R50 was almost equal to or even slightly above R150. Spring-time soil moisture replenishment from ice and snow melt caused the soil moisture in R50 to reach the maximum threshold for soil respiration in the study area. Increased precipitation produced little or no effect on soil respiration.

Soil respiration is the comprehensive result of autotrophic respiration mainly based on root activity and heterotrophic respiration related to soil organic matter decomposition (Wang et al. 2014). In our experiment, despite other contributory factors including root biomass, $\mathrm{pH}$, and fungal Shannon diversity, multiple regression analysis showed that soil moisture was the best predictor of soil respiration. Stepwise regression showed a significant positive linear correlation between soil moisture and soil respiration throughout the plant growth period, with the strongest correlation at the end of July (peak of summer) $\left(\mathrm{R}^{2}=0.87\right)$. In arid areas, concentrated and heavy precipitation events can greatly stimulate soil respiration (Liu et al. 2016), which our results support (Alwyn Sowerby et al. 2008; Emmett et al. 2004; Lellei-Kovács et al. 2011; Zhang et al. 2010). Drought can reduce the diffusion of organic substrates and decrease extracellular enzyme activity, thereby inhibiting root growth and microbial activity and impacting heterotrophic respiration (Liu et al. 2016). Our study area was confined to an arid area, which may limit the broader applications of our responses. Future climate change in precipitation may be mostly concentrated in a series of ecosystem responses caused by decreased precipitation and repeated samples should be taken in R50 and at even lower soil moisture levels.

\section{Conclusions}

In summary, our research showed that both increased and decreased precipitation treatments reduced the root biomass of plants and increased the shoot/root ratio. Precipitation changes caused significant changes in soil moisture, soil temperature, and soil respiration during the whole plant growing season in the study area, but moisture became non-limiting during heavy 
352 precipitation episodes at the height of the growing season. Changes in precipitation treatments

353 significantly affected soil nutrients ( $\mathrm{SOC}, \mathrm{TN}$ and $\mathrm{pH}$ ) across all soil depths, especially in the 354 topsoil. Though significantly affected by soil depth, microbial diversity and richness were not

sensitive to precipitation treatments. Overall, in arid grassland ecosystems where water is the limiting factor, the ecological response to changes in soil moisture caused by precipitation changes should be a key research topic to deepen our understanding of soil respiration in the future.

\section{Acknowledgements}

We thank all reviewers for their comments on the manuscript. We acknowledge all our team members for their help with field experiments.

\section{References}

Afreen T, and Singh H. 2019. Does change in precipitation magnitude affect the soil respiration response? A study on constructed invaded and uninvaded tropical grassland ecosystem. Ecological Indicators 102:84-94. DOI 10.1016/j.ecolind.2019.02.022.

Ahlström A, Raupach MR, Schurgers G, Smith B, Arneth A, Jung M, Reichstein M, Canadell JG, Friedlingstein P, Jain AK, Kato E, Poulter B, Sitch S, Stocker BD, Viovy N, Wang Y, Wiltshire A, Zaehle S, and Zeng N. 2015. The dominant role of semi-arid ecosystems in the trend and variability of the land $\mathrm{CO}_{2}$ sink. Science 348:895899.

Almagro M, Lopez J, Querejeta $\mathrm{Jl}$, and Martinez-Mena M. 2009. Temperature dependence of soil $\mathrm{CO}_{2}$ efflux is strongly modulated by seasonal patterns of moisture availability in a Mediterranean ecosystem. Soil Biology and Biochemistry 41:594-605. DOI 10.1016/j.soilbio.2008.12.021.

Alwyn Sowerby, Bridget A. Emmett, Albert Tietema, and Claus Beier. 2008. Contrasting effects of repeated summer drought on soil carbon efflux in hydric and mesic heathland soils. Global Change Biology 14:2388-2404. DOI 10.1111/j.1365-2486.2008.01643.x.

Bachar A, Al-Ashhab A, Soares MIM, Sklarz MY, Angel R, Ungar ED, and Gillor O. 2010. Soil microbial abundance and diversity along a low precipitation gradient. Microbial Ecology 60:453-461. DOI 10.1007/s00248-0109727-1.

Balogh J, Pintér K, Fóti S, Cserhalmi D, Papp M, and Nagy Z. 2011. Dependence of soil respiration on soil moisture, clay content, soil organic matter, and $\mathrm{CO}_{2}$ uptake in dry grasslands. Soil Biology and Biochemistry 43:10061013. DOI 10.1016/j.soilbio.2011.01.017.

Boone RD, Nadelhoffer KJ, Canary JD, and Kaye JP. 1998. Roots exert a strong influence on the temperature sensitivityof soil respiration. Nature 396:570-572. DOI 10.1038/25119.

Bremner DC, and Mulvaney JM. 1982. Methods of soil analysis. Madison, Wisconsin: American Society of Agronomy, Soil Science Society of America.

Peer] reviewing PDF | (2020:05:49410:3:0:NEW 16 Dec 2020) 
387

388

389

390

391

392

393

394

395

396

397

398

399

400

401

402

403

404

405

406

407

408

409

410

411

412

413

414

415

416

417

418

419

420

421

422

423

424

425

426

427
Chao A. 1984. Nonparametric estimation of the number of classes in a population. Scandinavian Journal of statistics 4:265-270.

Classen AT, Sundqvist MK, Henning JA, Newman GS, Moore JAM, Cregger MA, Moorhead LC, and Patterson CM. 2015. Direct and indirect effects of climate change on soil microbial and soil microbial-plant interactions: What lies ahead? Ecosphere 6:1-21. DOI 10.1890/es15-00217.1.

Crowther TW, and Bradford MA. 2013. Thermal acclimation in widespread heterotrophic soil microbes. Ecology Letters 16:469-477. DOI 10.1111/ele.12069.

Emmett BA, Beier C, Estiarte M, Tietema A, Kristensen HL, Williams D, Peñuelas J, Schmidt I, and Sowerby A. 2004. The response of soil processes to climate change: results from manipulation studies of shrublands across an environmental gradient. Ecosystems 7:625-637. DOI 10.1007/s10021-004-0220-x.

Felton AJ, Knapp AK, and Smith MD. 2019. Carbon exchange responses of a mesic grassland to an extreme gradient of precipitation. Oecologia 189:565-576. DOI 10.1007/s00442-018-4284-2.

Feng Z, An C, and Wang H. 2006. Holocene climatic and environmental changes in the arid and semi-arid areas of China: a review. The Holocene 16:119-130. DOI 10.1191/0959683606hl912xx.

Fernandez DP, Neff JC, Belnap J, and Reynolds RL. 2006. Soil respiration in the cold desert environment of the Colorado Plateau (USA): abiotic regulators and thresholds. Biogeochemistry 78:247-265. DOI 10.1007/s10533-005-4278-0.

Fischlin A, Midgley GF, Price JT, Leemans R, Gopal B, Turley C, Rounsevell MDA, Dube OP, Tarazona J, and Velichko A. 2007. Ecosystems, their properties, goods, and services. Cambridge: Cambridge University Press.

Frank D, Reichstein M, Bahn M, Thonicke K, Frank D, Mahecha MD, Smith P, Velde MV, Vicca S, Babst F, Beer C, Buchmann N, Canadell JG, Ciais P, Cramer W, Ibrom A, Miglietta F, Poulter B, Rammig A, Seneviraten SI, Walz A, Wattenbach M, Zavala MG, and Zscheischler J. 2015. Effects of climate extremes on the terrestrial carbon cycle: concepts, processes and potential future impacts. Global Change Biology 21:2861-2880. DOI 10.1111/gcb.12916.

Gao Q, Guo Y, Xu H, Ganjurjav H, Li Y, Wan Y, Qin X, Ma X, and Liu S. 2016. Climate change and its impacts on vegetation distribution and net primary productivity of the alpine ecosystem in the Qinghai-Tibetan Plateau. Science of the Total Environment 554:34-41. DOI org/10.1016/j.scitotenv.2016.02.131.

Garrett KA, Dendy SP, Frank EE, Rouse MN, and Travers SE. 2006. Climate change effects on plant disease: genomes to ecosystems. Annual Review of Phytopathology 44:489-509. DOI 10.1146/ annurev.phyto.44.070505.143420.

Geng Y, Wang Y, Yang K, Wang S, Zeng H, Baumann F, Kuehn P, Scholten T, and He J. 2012. Soil respiration in Tibetan alpine grasslands: belowground biomass and soil moisture, but not soil temperature, best explain the large-scale patterns. PLoS One 7:e34968. DOI 10.1371/journal.pone.0034968.

Gerten D, Luo Y, Le Maire G, Parton WJ, Keough C, Weng E, Beier C, Ciais P, Cramer W, Dukes JS, Hanson PJ, Knapp AAK, Linder S, Nepstad D, Rustad L, and Sowerby A. 2008. Modelled effects of precipitation on ecosystem carbon and water dynamics in different climatic zones. Global Change Biology 14:2365-2379. DOI 10.1111/j.1365-2486.2008.01651.x.

Good IJ. 1953. The population frequencies of species and the estimation of population parameters. Biometrika 40:237-264.

Hawkins BA, Field R, Cornell HV, Currie DJ, Guégan J-F, Kaufman DM, Kerr JT, Mittelbach GG, Oberdorff T, O'Brien EM, Porter EE, and Turner JRG. 2003. Energy, water, and broad-scale geographic patterns of species

PeerJ reviewing PDF | (2020:05:49410:3:0:NEW 16 Dec 2020) 
richness. Ecology 84:3105-3117. DOI org/10.1890/03-8006.

Huang J, Ji M, Xie Y, Wang S, He Y, and Ran J. 2015. Global semi-arid climate change over last 60 years. Climate Dynamics 46:1131-1150. DOI 10.1007/s00382-015-2636-8.

IPCC. 2001. Climate Change 2001: The Scientific Basis. In: Houghton J, Ding Y, Griggs D, Noguer M, Van der Linden P, Dai X, Maskell K, and Johnson C, editors. Cambridge: The press syndicate of the university of Cambridge.

Jing X, Huang J, Wang G, Higuchi K, Bi J, Sun Y, Yu H, and Wang T. 2010. The effects of clouds and aerosols on net ecosystem $\mathrm{CO}_{2}$ exchange over semi-arid Loess Plateau of Northwest China. Atmospheric Chemistry and Physics 10:8205-8218. DOI 10.5194/acp-10-8205-2010.

Kang S, Kim S, Oh S, and Lee D. 2000. Predicting spatial and temporal patterns of soil temperature based on topography, surface cover and air temperature. Forest Ecology and Management 136:173-184. DOI 10.1016/S0378-1127(99)00290-X.

Knapp AK, Fay PA, Blair JM, Collins SL, Smith MD, Carlisle JD, Harper CW, Danner BT, Lett MS, and McCarron JK. 2002. Rainfall variability, carbon cycling, and plant species diversity in a mesic grassland. Science 298:2202-2205.

Lellei-Kovács E, Kovács-Láng E, Botta-Dukát Z, Kalapos T, Emmett B, and Beier C. 2011. Thresholds and interactive effects of soil moisture on the temperature response of soil respiration. European Journal of Soil Biology 47:247-255. DOI 10.1016/j.ejsobi.2011.05.004.

Lemos LN, Fulthorpe RR, Triplett EW, and Roesch LFW. 2011. Rethinking microbial diversity analysis in the high throughput sequencing era. J Microbiol Methods 86:42-51. DOI 10.1016/j.mimet.2011.03.014.

Li G, Han H, Du Y, Hu D, Xia J, Niu S, Li X, and Wan S. 2017. Effects of warming and increased precipitation on net ecosystem productivity: A long-term manipulative experiment in a semiarid grassland. Agricultural and Forest Meteorology 232:359-366. DOI 10.1016/j.agrformet.2016.09.004.

Liu L, Wang X, Lajeunesse MJ, Miao G, Piao S, Wan Q, Wu Y, Wang Z, Yang S, Li P, and Deng M. 2016. A cross-biome synthesis of soil respiration and its determinants under simulated precipitation changes. Global Change Biology 22:1394-1405. DOI 10.1111/gcb.13156.

Maes WH, and Steppe K. 2012. Estimating evapotranspiration and drought stress with ground-based thermal remote sensing in agriculture: a review. Experimental Botany 63:4671-4712. DOI 10.1093/jxb/ers.165.

National Soil Survey Office. 1993. Soils of China. Beijing: China Agriculture Press. (In Chinese).

Niu F, Chen J, Xiong P, Wang Z, Zhang H, and Xu B. 2019. Responses of soil respiration to rainfall pulses in a natural grassland community on the semi-arid Loess Plateau of China. Catena 178:199-208. DOI 10.1016/j.catena.2019.03.020.

O'Gorman PA, and Schneider T. 2009. The physical basis for increases in precipitation extremes in simulations of 21st-century climate change. PNAS 106:14773-14777. DOI 10.1073/pnas.0907610106.

Ozalp M, Erdogan Yuksel E, and Yuksek T. 2016. Soil property changes after conversion from forest to pasture in Mount Sacinka, Artvin, Turkey. Land Degradation \& Development 27:1007-1017. DOI 10.1002/ldr.2353.

Pall P, Allen MR, and Stone DA. 2006. Testing the Clausius-Clapeyron constraint on changes in extreme precipitation under $\mathrm{CO}_{2}$ warming. Climate Dynamics 28:351-363. DOI 10.1007/s00382-006-0180-2.

Peng S, Piao S, Wang T, Sun J, and Shen Z. 2009. Temperature sensitivity of soil respiration in different ecosystems in China. Soil Biology \& Biochemistry 41:1008-1014. DOI 10.1016/j.soilbio.2008.10.023.

Poulter B, Frank D, Ciais P, Myneni RB, Andela N, Bi J, Broquet G, Canadell JG, Chevallier F, Liu Y, Running SW, Sitch $\mathrm{S}$, and van der Werf GR. 2014. Contribution of semi-arid ecosystems to interannual variability of the global 
carbon cycle. Nature 509:600. DOI 10.1038/nature13376.

Qiu L, Zhang X, Cheng J, and Han X. 2009. Effects of 22 years of re-vegetation on soil quality in the semi-arid area of the Loess Plateau. African Journal of Biotechnology 8:6896-6907. DOI 10.4314/ajb.v8i24.68773.

Schlesinger WH, and Andrew JA. 2000. Soil respiration and the global carbon cycle. Biogeochemistry 48:7-20. DOI 10.1023/A:1006247623877.

Schwinning S, and Sala OE. 2004. Hierarchy of responses to resource pulses in arid and semi-arid ecosystems. Oecologia 141:211-220. DOI 10.1007/s00442-004-1520-8.

Shipley B, and Meziane D. 2002. The balanced-growth hypothesis and the allometry of leaf and root biomass allocation. Functional Ecology 16:326-331. DOI org/10.1046/j.1365-2435.2002.00626.x.

Thomey ML, Collins SL, Vargas R, Johnson JE, Brown RF, Natvig DO, and Friggens MT. 2011. Effect of precipitation variability on net primary production and soil respiration in a Chihuahuan Desert Grassland. Global Change Biology 17:1505-1515. DOI 10.1111/j.1365-2486.2010.02363.x.

Treves DS, Xia B, Zhou J, and Tiedje JM. 2003. A two-species test of the hypothesis that spatial isolation influences microbial diversity in soil. Microbial Ecology 45:20-28. DOI 10.1007/s00248-002-1044-x.

Wang S, Fu B, Gao G, Liu Y, and Zhou J. 2013. Responses of soil moisture in different land cover types to rainfall events in a re-vegetation catchment area of the Loess Plateau, China. Catena 101:122-128. DOI 10.1016/j.catena.2012.10.006.

Wang S, Fu B, Gao G, and Zhou J. 2012. The hydrological responses of different land cover types in a re-vegetation catchment area of the Loess Plateau, China. Hydrology and Earth System Sciences Discussions 9:58095835. DOI 10.5194/hessd-9-5809-2012.

Wang X, Liu L, Piao S, Janssens IA, Tang J, Liu W, Chi Y, Wang J, and Xu S. 2014. Soil respiration under climate warming: differential response of heterotrophic and autotrophic respiration. Global Change Biology 20:3229-3237. DOI 10.1111/gcb.12620.

Wang Y, Li J, Jing L, Zhang Y, and Zhang J. 2020. Effects of different precipitation treatments on soil ecological chemistry and microbial diversity in the Loess Plateau. Acta Ecologica Sinica 40:1517-1531. DOI 10.5846/stxb201902150270. (In Chineses)

Wu S, Yin Y, Zhao D, Huang M, Shao X, and Dai E. 2009. Impact of future climate change on terrestrial ecosystems in China. International Journal of Climatology 30:866-873. DOI 10.1002/joc.1938.

Wu Z, Dijkstra P, Koch GW, Peñuelas J, and Hungate BA. 2011. Responses of terrestrial ecosystems to temperature and precipitation change: a meta-analysis of experimental manipulation. Global Change Biology 17:927942. DOI 10.1111/j.1365-2486.2010.02302.x.

Yuan Z, Jiao F, Shi X, Sardans J, Delgado-Baquerizo M, Maestre FT, Reich PB, and Peñuelas J. 2017. Experimental and observational studies find contrasting responses of soil nutrients to climate change. Elife 6:1-19. DOI 10.7554/eLife.23255.

Yuste JC, Baldocchi DD, Gershenson A, Goldstein A, Misson L, and Wong S. 2007. Microbial soil respiration and its dependency on carbon inputs, soil temperature and moisture. Global Change Biology 13:2018-2035. DOI 10.1111/j.1365-2486.2007.01415.x.

Zhang C, Liu G, Xue S, and Wang G. 2016. Soil bacterial community dynamics reflect changes in plant community and soil properties during the secondary succession of abandoned farmland in the Loess Plateau. Soil Biology and Biochemistry 97:40-49. DOI 10.1016/j.soilbio.2016.02.013.

Zhang L, Chen Y, Zhao R, and Li W. 2010. Significance of temperature and soil water content on soil respiration in 
510

511

512

513

514

515

516

517

518

519

520

521

522

523 three desert ecosystems in Northwest China. Journal of Arid Environments 74:1200-1211. DOI 10.1016/j.jaridenv.2010.05.031.

Zhang L, Zheng Q, Liu Y, Liu S, Yu D, Shi X, Xing S, Chen H, and Fan X. 2019a. Combined effects of temperature and precipitation on soil organic carbon changes in the uplands of eastern China. Geoderma 337:1105-1115. DOI 10.1016/j.geoderma.2018.11.026.

Zhang R, Zhao X, Zuo X, Qu H, Degen AA, Luo Y, Ma X, Chen M, Liu L, and Chen J. 2019b. Impacts of precipitation on ecosystem carbon fluxes in desert-grasslands in Inner Mongolia, China. Journal of Geophysical ResearchAtmospheres 124:1266-1276. DOI 10.1029/2018JD028419.

Zhao T, Chen L, and Ma Z. 2014. Simulation of historical and projected climate change in arid and semiarid areas by CMIP5 models. Science Bulletin 59:412-429. DOI 10.1007/s11434-013-0003-x.

Zimmermann M, Meir P, Bird MI, Malhi Y, and Ccahuana AJQ. 2010. Temporal variation and climate dependence of soil respiration and its components along a $3000 \mathrm{~m}$ altitudinal tropical forest gradient. Global Biogeochemical Cycles 24:GB4012. DOI 10.1029/2010GB003787. 
Figure 1

Rain-shelter construction and layout of the subplots at the study area.

Notes. Three precipitation treatments were applied: R50 ( $=50 \%$ of ambient precipitation), R100 (ambient) and R150 (= 150\% of ambient precipitation).

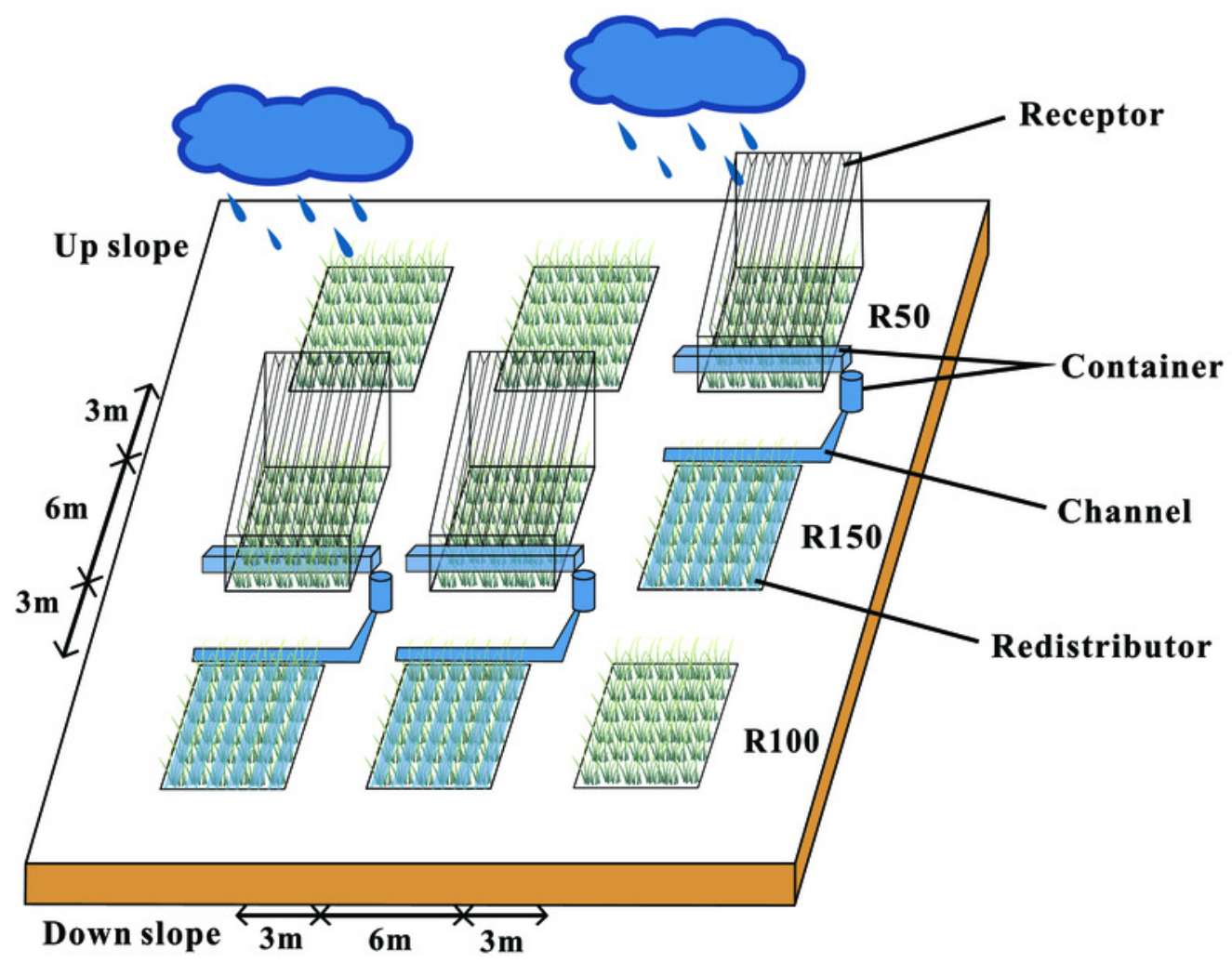


Figure 2

Monthly precipitation at the study site from 2017 to 2019 (bars) and average monthly temperature (T2019) in 2019 (black line and points).

Notes. Meteorological data were obtained from the National Meteorological Administration of China.

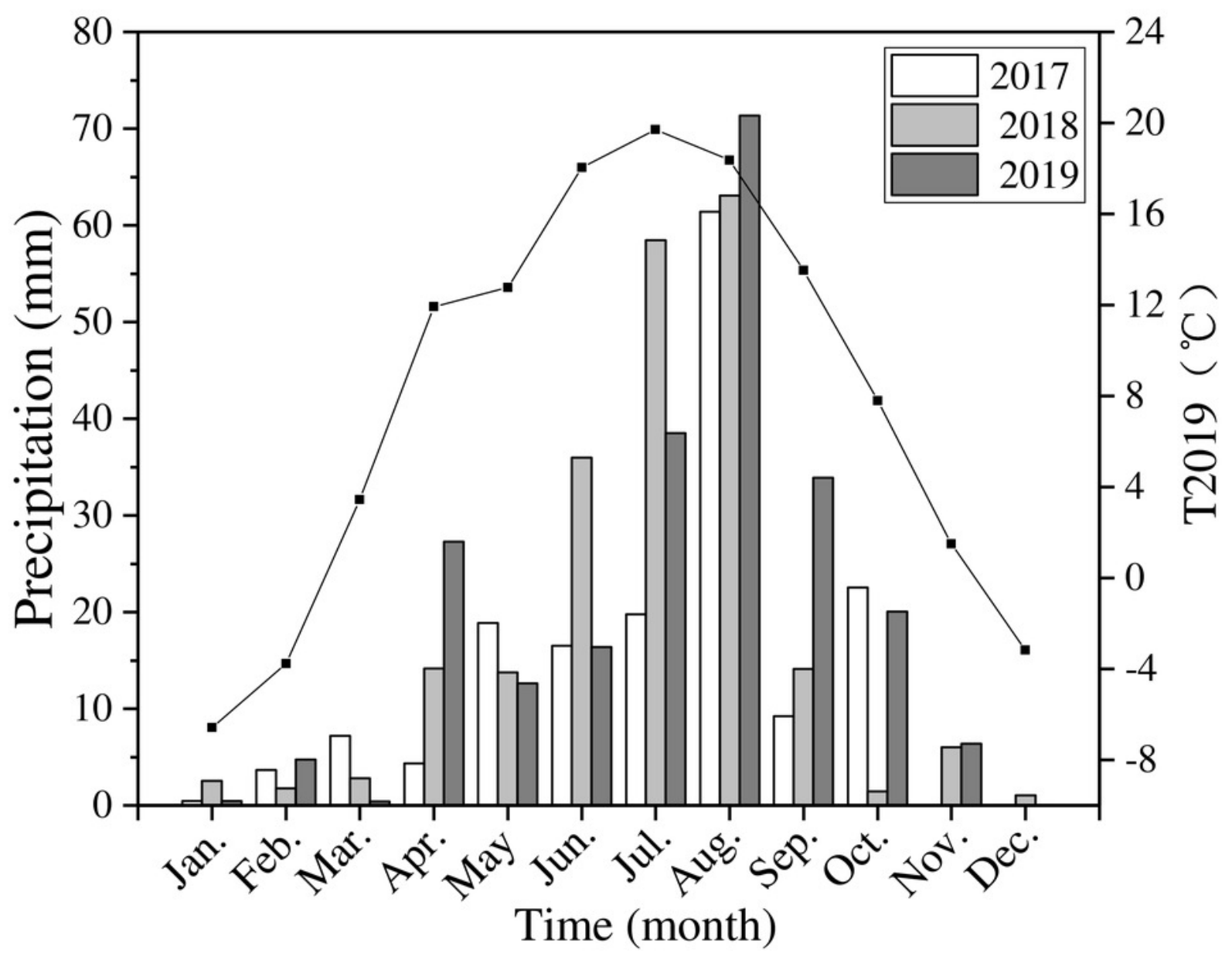


Figure 3

Biomass of shoot, litter, roots, total biomass (TB) and shoot/root ratio for each precipitation.

Notes. Different letters within each tissue type show significant differences $(P<0.05)$ between precipitation treatments according to one-way ANOVA (mean \pm standard error, $\mathrm{n}=$ 3) . Shoot, litter, roots and TB use the left $Y$ axis, and shoot/root the right.

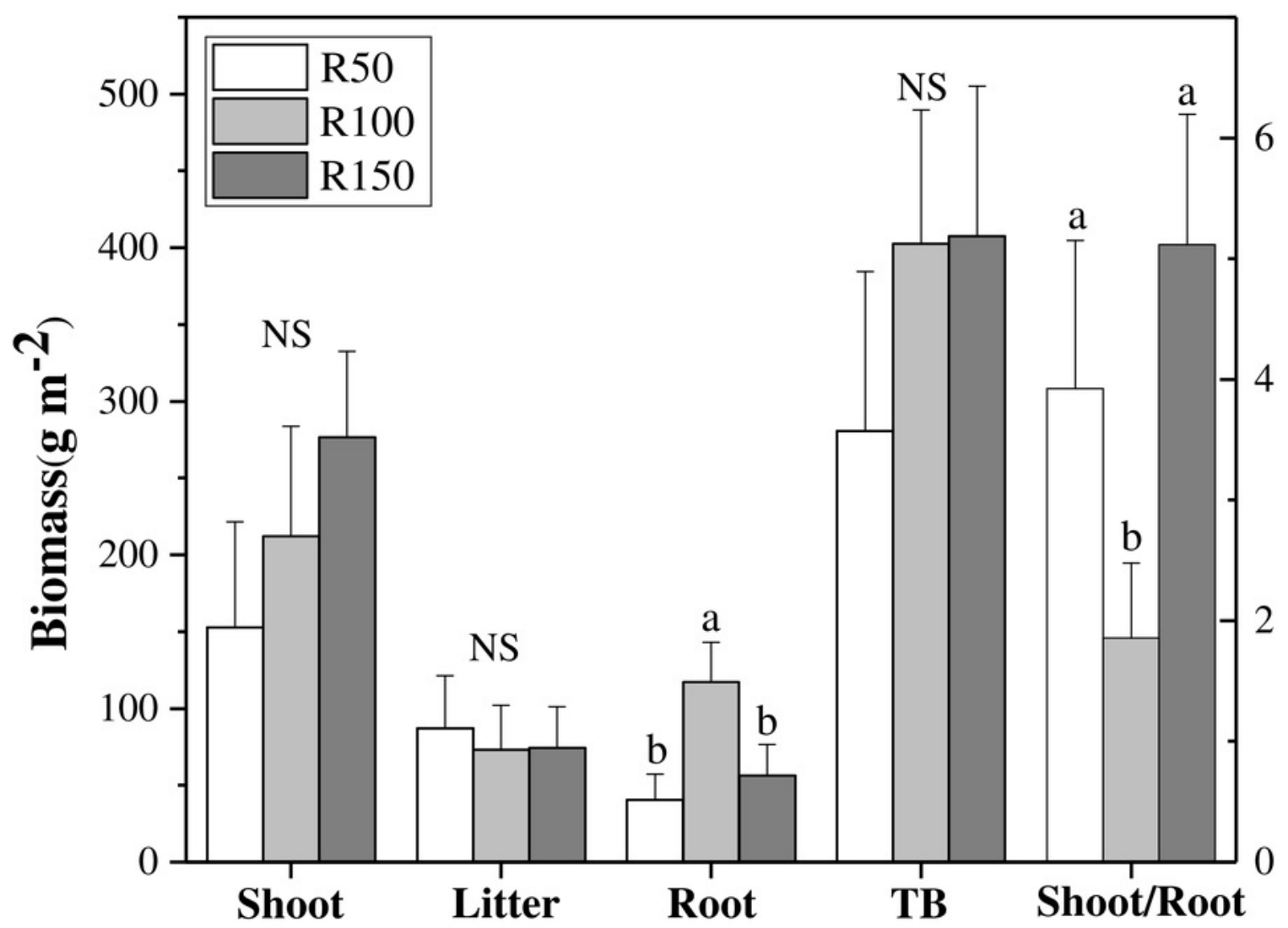


Figure 4

Root biomass at different soil depths in three precipitation treatments.

Notes. Different letters show significant differences $(P<0.05)$ between precipitation treatments and soil depths according to two-way ANOVA (mean \pm standard error, $\mathrm{n}=3$ ).

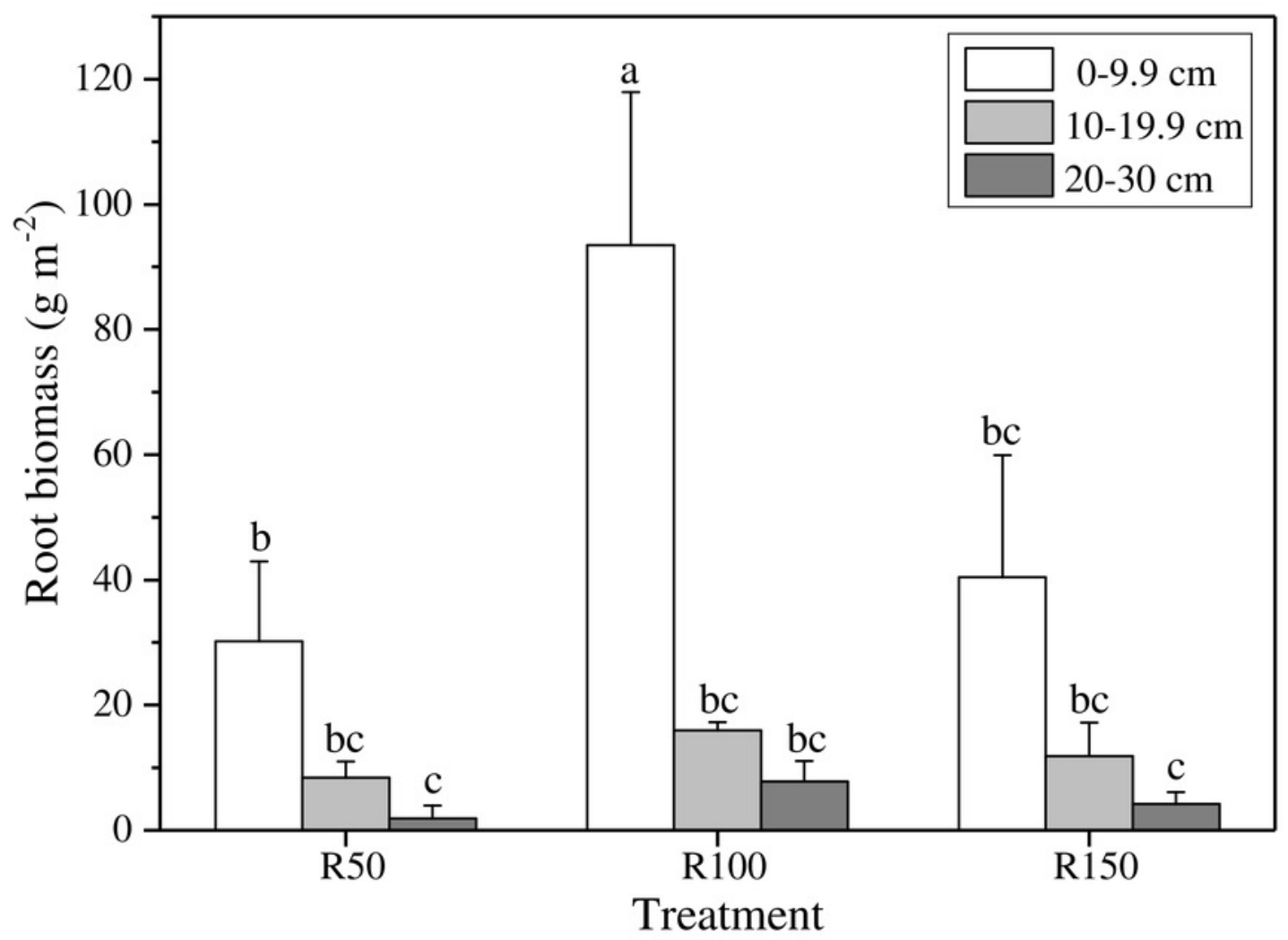


Figure 5

Interactions of precipitation treatments and times for soil moisture, soil temperature and soil $\mathrm{CO}_{2}$ flux during the growing season.

Notes. Values are the mean \pm standard error $(n=3)$.
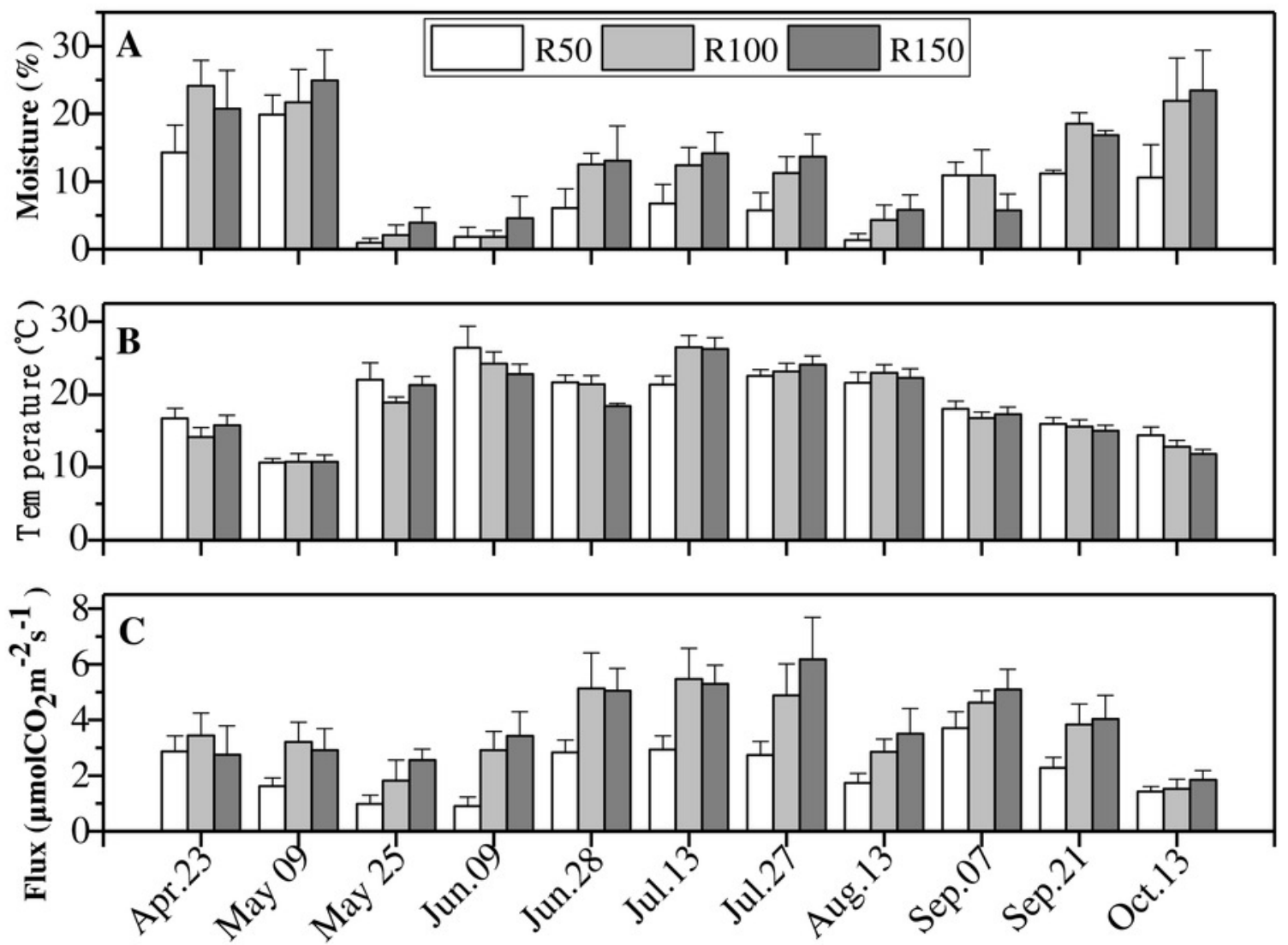

Time (Day) 


\section{Table $\mathbf{1}$ (on next page)}

Soil nutrient content and soil pH in different precipitation treatments and soil depths.

Notes. Pre=Precipitation; SD=soil depth; SD1=soil depth $0-9.9 \mathrm{~cm} ; \mathrm{SD} 2=$ soil depth

10-19.9cm; SD3=soil depth $20-30 \mathrm{~cm}$; Pre* SD= Precipitation * soil depth. Values are mean \pm

standard error $(\mathrm{n}=3)$. Means in a row without a common superscript letter differ $(P<0.05)$ as analyzed by two-way ANOVA. 


\begin{tabular}{|c|c|c|c|c|c|c|c|c|c|c|c|c|}
\hline & R50 & & & $\mathrm{R} 100$ & & & $\mathrm{R} 150$ & & & $\mathrm{P}-\mathrm{Va}$ & & \\
\hline $\mathrm{s}$ & SD1 & SD2 & SD3 & SD1 & SD2 & SD3 & SD1 & SD2 & SD3 & Pre & SD & $\begin{array}{l}\text { Pre* } \\
\text { SD }\end{array}$ \\
\hline $\mathrm{TN}$ & $2.3 \pm 0.1$ & $2.1 \pm 0.1$ & $1.9 \pm 0.1$ & $2.4 \pm 0.0$ & $2.1 \pm 0.0$ & $2.1 \pm 0.1$ & $2.3 \pm 0.1$ & $2.0 \pm 0.1$ & $2.0 \pm 0.0$ & & & \\
\hline (g kg-1) & $\mathrm{a}$ & $\mathrm{b}$ & $\mathrm{b}$ & $\mathrm{a}$ & $\mathrm{b}$ & $\mathrm{b}$ & $\mathrm{a}$ & $\mathrm{b}$ & $\mathrm{b}$ & 0.041 & 0.000 & 0.253 \\
\hline $\begin{array}{l}\text { SOC } \\
(\mathrm{g} \mathrm{kg}-1)\end{array}$ & $\begin{array}{l}8.1 \pm 0.1 \\
\mathrm{a}\end{array}$ & $\begin{array}{l}6.1 \pm 0.3 \\
\text { bc }\end{array}$ & $\begin{array}{l}6.2 \pm 0.2 \\
\mathrm{c}\end{array}$ & $\begin{array}{l}8.0 \pm 0.0 \\
\text { a }\end{array}$ & $\begin{array}{l}7.0 \pm 0.1 \\
\mathrm{~b}\end{array}$ & $\begin{array}{l}6.6 \pm 0.3 \\
\text { bc }\end{array}$ & $\begin{array}{l}7.7 \pm 0.3 \\
\mathrm{a}\end{array}$ & $\begin{array}{l}6.8 \pm 0.2 \\
\text { bc }\end{array}$ & $\begin{array}{l}6.6 \pm 0.3 \\
\text { bc }\end{array}$ & 0.045 & 0.000 & 0.049 \\
\hline $\begin{array}{l}\text { TP } \\
(\mathrm{g} \mathrm{kg}-1)\end{array}$ & $0.7 \pm 0.0$ & $0.7 \pm 0.0$ & $0.7 \pm 0.0$ & $0.7 \pm 0.0$ & $0.8 \pm 0.0$ & $0.7 \pm 0.0$ & $0.7 \pm 0.0$ & $0.7 \pm 0.0$ & $0.7 \pm 0.0$ & 0.231 & 0.687 & 0.213 \\
\hline $\mathrm{pH}$ & $\begin{array}{l}7.8 \pm 0.1 \\
\mathrm{ab}\end{array}$ & $\begin{array}{l}7.8 \pm 0.1 \\
\mathrm{ab}\end{array}$ & $\begin{array}{l}7.9 \pm 0.1 \\
\mathrm{ab}\end{array}$ & $\begin{array}{l}7.8 \pm 0.1 \\
\mathrm{ab}\end{array}$ & $8.0 \pm 0.2$ & $8.1 \pm 0.1$ & $7.7 \pm 0.1$ & $\begin{array}{l}7.9 \pm 0.1 \\
\mathrm{ab}\end{array}$ & $\begin{array}{l}8.0 \pm 0.2 \\
\mathrm{ab}\end{array}$ & 0.022 & 0.003 & 0.626 \\
\hline
\end{tabular}

1 


\section{Table 2 (on next page)}

Alpha diversity of bacteria and fungi under different precipitation treatments and soil depths.

Notes. $B=$ Bacteria; cov=coverage; $F=$ Fungi; Community richness (Sobs' index), community diversity (Shannon's index) and community coverage (of OTUs) of bacteria and fungi under different precipitation treatments and soil depths. Different letters show significantly different values between depths within each precipitation treatment. 


\begin{tabular}{|c|c|c|c|c|c|c|c|c|c|c|c|}
\hline \multirow{2}{*}{ Variables } & \multicolumn{3}{|l|}{ R50 } & \multicolumn{3}{|l|}{ R100 } & \multicolumn{3}{|l|}{$\mathrm{R} 150$} & \multicolumn{2}{|c|}{ P-Value } \\
\hline & SD1 & $\mathrm{SD} 2$ & SD3 & SD1 & $\mathrm{SD} 2$ & SD3 & SD1 & $\mathrm{SD} 2$ & SD3 & Pre & SD \\
\hline B_Sobs & $\begin{array}{l}2529 \\
\mathrm{a}\end{array}$ & $\begin{array}{l}2183 \\
b\end{array}$ & $\begin{array}{l}2037 \\
b c\end{array}$ & $\begin{array}{l}2615 \\
a\end{array}$ & $\begin{array}{l}2157 \\
b\end{array}$ & $\begin{array}{l}2024 \\
\text { bc }\end{array}$ & $\begin{array}{l}2530 \\
\mathrm{a}\end{array}$ & $\begin{array}{l}2222 \\
\mathrm{~b}\end{array}$ & $\begin{array}{l}1880 \\
\mathrm{c}\end{array}$ & 0.46 & 0.00 \\
\hline B_Shannon & $\begin{array}{l}6.7 \\
a b\end{array}$ & $\begin{array}{l}6.3 \\
d\end{array}$ & $\begin{array}{l}6.2 \\
d\end{array}$ & $\begin{array}{l}6.7 \\
a\end{array}$ & $\begin{array}{l}6.4 \\
\mathrm{~cd}\end{array}$ & $\begin{array}{l}6.2 \\
d\end{array}$ & $\begin{array}{l}6.6 \\
a b c\end{array}$ & $\begin{array}{l}6.4 \\
\text { bcd }\end{array}$ & $\begin{array}{l}6.2 \\
d\end{array}$ & 0.44 & 0.00 \\
\hline B_Cov $(\%)$ & 96.0 & 96.4 & 96.5 & 95.8 & 96.4 & 96.6 & 95.8 & 96.3 & 96.9 & 0.82 & 0.01 \\
\hline F_Sobs & $\begin{array}{l}725 \\
a b\end{array}$ & $\begin{array}{l}528 \\
\text { abcd }\end{array}$ & $\begin{array}{l}491 \\
\text { bcd }\end{array}$ & $\begin{array}{l}755 \\
a\end{array}$ & $\begin{array}{l}458 \\
\mathrm{~cd}\end{array}$ & $\begin{array}{l}414 \\
\mathrm{~cd}\end{array}$ & $\begin{array}{l}632 \\
a b c\end{array}$ & $\begin{array}{l}490 \\
\text { bcd }\end{array}$ & $\begin{array}{l}352 \\
d\end{array}$ & 0.11 & 0.00 \\
\hline F_Shannon & $\begin{array}{l}4.3 \\
a b\end{array}$ & $\begin{array}{l}3.4 \\
\mathrm{ab}\end{array}$ & $\begin{array}{l}3.3 \\
a b\end{array}$ & $\begin{array}{l}4.5 \\
a b\end{array}$ & $\begin{array}{l}4.0 \\
a b\end{array}$ & $\begin{array}{l}3.2 \\
\mathrm{~b}\end{array}$ & $\begin{array}{l}4.7 \\
\mathrm{a}\end{array}$ & $\begin{array}{l}3.8 \\
a b\end{array}$ & $\begin{array}{l}3.7 \\
a b\end{array}$ & 0.33 & $\mathbf{0 . 0 0}$ \\
\hline F_Cov $(\%)$ & 99.8 & 99.8 & 99.9 & 99.8 & 99.9 & 99.9 & 99.9 & 99.9 & 99.9 & 0.02 & 0.00 \\
\hline
\end{tabular}

1

2 


\section{Table 3(on next page)}

ANOVAs for soil temperature, soil moisture and soil $\mathrm{CO}_{2}$ flux between precipitation treatments and dates during the whole experimental period.

Notes. num DF: number of degrees of freedom; den DF: the number of degrees of freedom associated with the model errors. 


\begin{tabular}{|c|c|c|c|c|c|c|c|c|}
\hline & \multirow{2}{*}{ numDF } & \multirow{2}{*}{ denDF } & \multicolumn{2}{|c|}{ Soil moisture } & \multicolumn{2}{|c|}{ Soil temperature } & \multicolumn{2}{|c|}{ Soil $\mathrm{CO}_{2}$ flux } \\
\hline & & & F-value & $P$-value & F-value & $P$-value & F-value & $P$-value \\
\hline Intercept & 1 & 60 & 822.1 & $<0.0001$ & 17856 & $<0.0001$ & 1626.0 & $<0.0001$ \\
\hline Pre treatments & 2 & 6 & 42.7 & 0.0003 & 5.4 & 0.046 & 55.9 & 0.0001 \\
\hline Dates & 10 & 60 & 414.5 & $<0.0001$ & 348.0 & $<0.0001$ & 156.7 & $<0.0001$ \\
\hline $\begin{array}{l}\text { Pre treatments } \\
* \text { Dates }\end{array}$ & 20 & 60 & 14.8 & $<0.0001$ & 8.0 & $<0.0001$ & 9.7 & $<0.0001$ \\
\hline
\end{tabular}

1 


\section{Table 4(on next page)}

Precipitation treatments differences for soil moisture, soil temperature and soil $\mathrm{CO}_{2}$ flux over the whole experimental period.

Notes. Values are the mean \pm standard error $(n=3)$. There are three precipitation treatments, and each treatment has three replicates. Sampling was conducted 11 times during the growing season. Different letters show significantly different between precipitation treatments $(P<0.05)$. 


\begin{tabular}{llll}
\hline Precipitations & R50 & R100 & R150 \\
\hline Mean soil moisture $(\%)$ & $8.1 \pm 2.3 \mathrm{~b}$ & $12.9 \pm 2.9 \mathrm{ab}$ & $13.4 \pm 3.5 \mathrm{a}$ \\
Mean soil temperature $\left({ }^{\circ} \mathrm{C}\right)$ & $19.2 \pm 1.3 \mathrm{a}$ & $18.9 \pm 1.1 \mathrm{a}$ & $18.7 \pm 1.1 \mathrm{a}$ \\
Mean soil $\mathrm{CO}_{2}$ flux $\left(\mu \mathrm{mol} \mathrm{CO} \mathrm{m}^{-2} \mathrm{~s}^{-1}\right)$ & $2.2 \pm 0.4 \mathrm{~b}$ & $3.6 \pm 0.8 \mathrm{ab}$ & $3.9 \pm 0.8 \mathrm{a}$ \\
\hline
\end{tabular}

1 


\section{Table 5 (on next page)}

Seasonal differences in soil moisture, temperature and $\mathrm{CO}_{2}$ flux across all precipitation treatments.

Notes. Values are the mean \pm standard error $(n=3)$. 


\begin{tabular}{llll}
\hline Date & Soil moisture $(\%)$ & Soil temperature $\left({ }^{\circ} \mathrm{C}\right)$ & Soil $\mathrm{CO}_{2}$ flux $\left(\mu \mathrm{mol} \mathrm{CO} \mathrm{CO}^{-2} \mathrm{~s}^{-1}\right)$ \\
\hline Apr. 23 & $19.7 \pm 4.5$ & $15.6 \pm 1.3$ & $3.02 \pm 0.8$ \\
May 09 & $22.2 \pm 4.1$ & $10.7 \pm 0.9$ & $2.58 \pm 0.6$ \\
May 25 & $2.3 \pm 1.4$ & $20.8 \pm 1.4$ & $1.78 \pm 0.5$ \\
Jun. 09 & $2.8 \pm 1.9$ & $24.5 \pm 2.0$ & $2.41 \pm 0.6$ \\
Jun. 28 & $10.6 \pm 3.2$ & $20.5 \pm 0.9$ & $4.33 \pm 0.8$ \\
Jul. 13 & $11.1 \pm 2.9$ & $24.7 \pm 1.5$ & $4.56 \pm 0.8$ \\
Jul. 27 & $10.2 \pm 2.8$ & $23.3 \pm 1.1$ & $4.59 \pm 1.1$ \\
Aug. 13 & $3.8 \pm 1.8$ & $22.3 \pm 1.2$ & $2.69 \pm 0.6$ \\
Sep. 07 & $9.2 \pm 2.7$ & $17.4 \pm 0.9$ & $4.48 \pm 0.6$ \\
Sep. 21 & $15.5 \pm 0.9$ & $15.5 \pm 0.9$ & $3.38 \pm 0.7$ \\
Oct. 13 & $18.7 \pm 5.7$ & $13.0 \pm 0.9$ & $1.59 \pm 0.3$ \\
\hline
\end{tabular}




\section{Table 6(on next page)}

The Predictive model of soil $\mathrm{CO}_{2}$ flux according to Stepwise regression.

Notes. It based on soil moisture and the most informative factors from the July

measurements of each of the sets of soil properties, plant factors and soil microbial diversity (Shannon index) in three precipitation treatments. 
1 Table 6 Stepwise regression to predict the main factors affecting soil respiration

\begin{tabular}{llllll}
\hline $\begin{array}{l}\text { Input } \\
\text { variable }\end{array}$ & excluded Variables & $\mathrm{R}$ & Adjust R & Sig & Durbin- \\
\hline Soil & RB 0-9.9cm, RB 0-9.9cm, & 0.941 & 0.870 & 0.00 & 2.727 \\
moisture & Soil pH, Soil fungal diversity & & & \\
\hline Model & Soil $\mathrm{CO}_{2}$ flux $=0.35+0.42$ Soil moisture & & \\
\hline
\end{tabular}

2 